\title{
Peran Guru dalam Mengembangkan Keterampilan Sosial Siswa Mata Pelajaran IPS di SMK
}

\author{
Mujiatin Setyana \\ SMKN 1 Ponorogo-Jl. Jenderal Sudirman 10 Ponorogo \\ Email: ana_setyana@yahoo.co.id
}

\begin{abstract}
This study aims to explain: 1) teachers' understanding of social skills in social studies at SMK; 2) the role of social studies teachers in vocational schools were in designing learning social studies students develop social skills; 3) the implementation of learning undertaken by teachers in vocational IPS that can develop social skills; 4) assessment conducted in vocational teachers in social studies is to develop social skills. The study used a qualitative descriptive research design with case study. The techniques used were interviews, observation and documentationThe results showed: teachers' understanding of the lack of social skills; RPP has not led to the development of social skills, cooperative learning models used in the learning is not maximized; assessment conducted by a social studies teacher tends cognitive, while the affective and psychomotor assessment ignored.
\end{abstract}

Key Words: roles of teachers, the learning of social studies, social skills

\begin{abstract}
Abstrak: Penelitian ini bertujuan untuk menjelaskan 1) pemahaman guru tentang keterampilan sosial pada mata pelajaran IPS di SMK; 2) peran guru-guru IPS di SMK dalam merancang pembelajaran IPS yang mengembangkan keterampilan sosial siswa; 3) pelaksanaan pembelajaran yang dilakukan oleh guru-guru IPS di SMK yang dapat mengembangkan keterampilan sosial; 4) penilaian yang dilakukan guru-guru di SMK pada mata pelajaran IPS yang mengembangkan keterampilan sosial. Penelitian menggunakan rancangan penelitian deskriptif kualitatif dengan studi kasus. Teknik yang digunakan adalah wawancara, observasi dan dokumentasi. Hasil penelitian menunjukkan: pemahaman guru tentang keterampilan sosial kurang; RPP belum mengarah pada pengembangan keterampilan sosial, model cooperative learning yang digunakan dalam pembelajaran belum maksimal; penilaian yang dilakukan oleh guru IPS cenderung kognitif, sedangkan penilaian afektif dan psikomotor diabaikan.
\end{abstract}

Kata kunci: peran guru, pembelajaran IPS, keterampilan sosial

Kehidupan abad-21 menuntut sejumlah keterampilan yang harus dimiliki oleh semua warga negara. Oleh karena itu menuntut sekolah untuk menyiapkan anak didik agar memiliki sejumlah keterampilan yang diperlukan untuk dapat hidup di abad-21. Maftuh (2010:4) menyatakan bahwa untuk bisa berperan secara bermakna pada era globalisasi di abad ke-21 ini maka setiap warga negara dituntut memiliki kemampuan yang berbeda dengan tuntutan kemampuan dasawarsa yang lalu.

IPS dapat memainkan peran pentingnya yakni pada kelompok keterampilan sosial seperti yang dikemukakan berbagai pendapat yang meliputi: keterampilan interpersonal, keterampilan bekerjasama (kolaborasi) lintas jaringan, keterampilan interaksi sosial dan lintas budaya, tanggung jawab personal dan sosial, komunikasi interaktif, literasi budaya dan kesadaran global.

Hal ini menuntut peran guru untuk mengembangkan keterampilan yang ada pada diri anak. Dalam mata pelajaran IPS, maka guru IPS harus dapat mengembangkan keterampilan-keterampilan yang dimiliki oleh anak didik, terutama keterampilan sosial. Dengan keterampilan sosial inilah diharapkan anak didik dapat hidup sesuai dengan tuntutan abad 21. Teori multiple intelligence menurut Gardner (1993:89) bahwa manusia tidak hanya memiliki inteligensi tunggal, akan tetapi memiliki 8 intelligence yaitu linguistic, logical-mathematical, spatial, musical, bodily-kinesthetic, interpersonal, intrapersonal, 
dan naturalistic. Setiap individu berbeda kekuatannya di masing-masing inteligensi. Berkaitan dengan pengembangan multiple intelligence, maka guru agar memahami keterampilan yang berkaitan dengan IPS. Salah satu keterampilan yang perlu dikembangkan oleh guru adalah keterampilan sosial, yang termasuk dalam interpersonal intelligence.

Guru memiliki posisi yang menentukan keberhasilan dalam pembelajaran, karena guru berperan sebagai planning for learning (perancang pembelajaran), managing learning (pengelola pembelajaran), dan evaluator of student learning (penilai prestasi belajar siswa) (Gagne, 1977:23). Guru sebagai perancang pembelajaran) menghendaki guru yang mampu untuk membuat rancangan pembelajaran sebelum melaksanakan pembelajaran yang sesuai dengan kebutuhan siswa. Sebagai pengelola pembelajaran (managing learning) maka diperlukan seorang guru yang mampu untuk mengelola seluruh aktivitas pembelajaran, karena melalui kegiatan pembelajaran tujuan pembelajaran akan dapat diwujudkan. Sedangkan peran guru sebagai evaluator of student learning, guru melakukan penilaian (evaluasi) terhadap hasil pembelajaran yang telah dilaksanakan.

Penelitian ini bertujuan untuk menjelaskan: 1) pemahaman guru tentang keterampilan sosial pada mata pelajaran IPS di SMK Negeri Kabupaten Ponorogo; 2) peran guru-guru IPS dalam merancang pembelajaran IPS untuk mengembangkan keterampilan sosial siswa di SMK Negeri Kabupaten Ponorogo; 3) pelaksanaan pembelajaran yang dilakukan oleh guru-guru IPS di SMK Negeri Kabupaten Ponorogo yang dapat mengembangkan keterampilan sosial; 4) penilaian yang dilakukan guru-guru di SMK Negeri Kabupaten Ponorogo pada mata pelajaran IPS yang mengembangkan keterampilan sosial.

\section{METODE}

Penelitian dilakukan di dua sekolah yaitu di SMK Negeri 1 Ponorogo dan SMK Negeri 1 Jenangan Ponorogo dengan menggunakan rancangan penelitian deskriptif kualitatif dengan studi kasus. Teknik yang digunakan adalah wawancara, observasi dan dokumentasi. Teknik wawancara dilakukan kepada guru untuk mengetahui pemahaman tentang keterampilan sosial siswa, wawancara kepada waka kurikulum untuk mengetahui cara penyusunan rancangan pelaksanaan pembelajaran, wawancara dengan siswa untuk mengetahui pendapat siswa tentang pelaksanaan pembelajaran yang dilakukan oleh guru. Observasi dilakukan untuk mengetahui secara langsung pelaksanaan pembelajaran yang dilakukan guru mata pelajaran IPS di kelas, sedangkan dokumentasi digunakan untuk mengetahui dokumen Rencana Pelaksanaan Pembelajaran (RPP) yang telah dibuat oleh guru.

Dalam penelitian ini peneliti sebagai instrumen kunci dan kehadiran peneliti sebagai pengamat partisipan dan pasif. Menurut Sugiyono (2011:227), pengamat partisipan pasif adalah "peneliti datang di tempat kegiatan orang yang diamati tetapi tidak ikut terlibat dalam kegiatan tersebut”. Sebagai sumber data adalah manusia yaitu guru dan siswa, sedangkan non manusia yaitu dokumen dan peristiwa atau kejadian selama kegiatan pelaksanaan pembelajaran berlangsung. Kegiatan peneliti dilokasi penelitian dimulai pada bulan April 2012. Kegiatan penelitian dikelompokkan menjadi 2, yaitu kegiatan wawancara dan kegiatan observasi. Kegiatan wawancara dilakukan terhadap guru, siswa dan waka kurikulum. Sedangkan kegiatan observasi dilakukan untuk mengamati kegiatan pelaksanaan pembelajaran yang berlangsung di kelas. Kegiatan wawancara dilakukan terhadap 10 informan, sedangkan observasi dilakukan terhadap 4 orang guru masing-masing 3 kali observasi dengan waktu 90 menit satu kali pertemuan.

Analisis data dilakukan dengan reduksi data, penyajian data dan penarikan simpulan. Data yang sudah diperoleh kemudian direduksi, kemudian disajikan. Setelah penyajian data baru diambil simpulan.

Pengecekan keabsahan data dilakukan melalui proses triangulasi sumber, metode dan member check. Triangulasi adalah teknik pemeriksaan data yang memanfaatkan sesuatu yang lain (Moleong, 1998:330).

Kegiatan triangulasi sumber dilakukan dengan membandingkan dan mengecek balik derajat kepercayaan suatu informasi yang diperoleh melalui waktu dan alat yang berbeda dalam penelitian kualitatif. Triangulasi sumber dilakukan dari hasil observasi dan wawancara terhadap informan, kemudian di triangulasi dengan informasi yang diberikan oleh waka kurikulum dan informasi dari siswa untuk mengecek kebenarannya.

Metode triangulasi adalah membandingkan data hasil pengamatan dengan data hasil wawancara dan kemudian di cek dengan isi dokumen yang berkaitan. Metode triangulasi dilakukan untuk mengecek data hasil kajian RPP yang telah dibuat oleh guru dan hasil observasi dengan aturan yang berlaku yaitu Standar Nasional Pendidikan dan Standar Proses yang merupakan pedoman dan kebijakan pemerintah yang berla- 
ku saat ini. Analisis RPP di triangulasi dengan Permendiknas No. 41 tahun 2007 tentang Standar Proses, RPP yang dibuat guru, dianalisa, dan disesuaikan dengan aturan-aturan dalam menyusun RPP yang berlaku.

Member check dilakukan dengan cara pengecekan data yang diperoleh peneliti kepada pemberi data. Tujuan member check adalah untuk mengetahui seberapa jauh data yang diperoleh sesuai dengan apa yang diberikan oleh pemberi data. Peneliti mendatangi setiap informan dan memperlihatkan data atau informasi yang telah diketik dalam bentuk transkrip wawancara, observasi, studi dokumen kepada para informan. Para informan diminta untuk membaca kembali dan menilai apakah perlu diperbaiki atau tidak. Jika data yang direkam peneliti tidak disepakati oleh pemberi data, peneliti perlu melakukan diskusi dengan pemberi data dan apabila terdapat perbedaan tajam setelah dilakukan diskusi peneliti harus mengubah temuannya dan menyesuaikan data yang diberikan oleh pemberi data.

\section{HASIL DAN PEMBAHASAN}

\section{Pemahaman Guru tentang Keterampilan Sosial}

Guru-guru IPS yang dijadikan sebagai sumber data memiliki latar belakang pendidikan sebagai berikut: 1 orang guru berlatar belakang Pendidikan Kewarganegaran, 1 orang guru berlatar belakang pendidikan S-1 Ekonomi dan S-2 Pendidikan IPS tetapi baru pindah dari SMA, 1 orang berlatar belakang S1 pendidikan Sejarah, dan seorang lagi berlatar belakang S-1 Ekonomi Akuntasi. Dari hasil wawancara mengenai keterampilan sosial, guru-guru mengatakan bahwa mereka memahami keterampilan sosial dan juga memahami tujuan IPS, serta pentingnya keterampilan sosial bagi kehidupan siswa di masa yang akan datang. Mereka berpendapat bahwa banyak orang-orang sukses yang tidak ber-IQ tinggi tetapi memiliki keterampailan sosial yang baik. Dengan keterampilan sosial maka siswa akan dapat hidup di tengah-tengah masyarakat global. Kebanyakan guru melihat keterampilan sosial terutama dari segi interaksi dengan orang lain dan kerjasama dengan orang lain.

Guru memiliki andil yang cukup besar terhadap keberhasilan pembelajaran di sekolah. Guru sangat berperan dalam membantu perkembangan peserta didik untuk mewujudkan tujuan hidupnya secara opti- mal (Mulyasa, 2011:35). Manusia adalah mahkluk lemah yang dalam perkembangannya membutuhkan orang lain atau ketergantungan dengan orang lain. Siswa perlu memiliki sejumlah keterampilan terutama keterampilan sosial untuk dapat hidup dengan orang lain, sehingga guru perlu memahami perannya untuk mengembangkan keterampilan sosial siswa agar mereka dapat hidup bermasyarakat.

Sebelum guru mata pelajaran IPS memahami tentang keterampilan sosial maka terlebih dahulu mengetahui tentang tujuan IPS. Mata pelajaran IPS bertujuan agar peserta didik memiliki kemampuan sebagai berikut. (1) Memahami konsep-konsep yang berkaitan dengan kehidupan masyarakat dan lingkungannya. (2) Berpikir logis dan kritis, rasa ingin tahu, memecahkan masalah, dan keterampilan dalam kehidupan sosial. (3) Berkomitmen terhadap nilainilai sosial dan kemanusiaan. (4) Berkomunikasi, bekerjasama dan berkompetisi dalam masyarakat yang majemuk di tingkat lokal, nasional, dan global (Gunawan, 2011:39).

Apabila seorang guru telah mengetahui tujuan IPS maka guru akan dapat memahami bahwa mata pelajaran IPS bukan sekedar mata pelajaran hafalan konsep-konsep saja akan tetapi mata pelajaran ini merupakan mata pelajaran yang mengajarkan berbagai keterampilan yaitu keterampilan berfikir logis, berkomunikasi, bekerjasama dan berkompetisi di masyarakat.

Pemahaman guru terhadap keterampilan sosial sangat penting, mengingat peran guru sebagai perancang pembelajaran, pelaksana pembelajaran dan penilai dalam proses pembelajaran. Apabila guru memahami pentingnya keterampilan sosial ini maka guru akan merubah cara pembelajaran atau cara mengajarnya. Dalam praktik di lapangan, walaupun guru mengaku memahami tujuan IPS yang mengarah pada pengembangan keterampilan sosial tetapi kenyataannya pembelajaran IPS masih banyak mengandalkan hafalan materi saja.

\section{Peran Guru dalam Merancang Pelaksanaan Pembelajaran}

RPP yang dibuat guru merupakan pedoman guru untuk melaksanakan pembelajaran di kelas. Menyusun RPP merupakan tugas guru yang harus dilaksanakan dan RPP sudah disusun sebelum pelaksanaan pembelajaran di kelas.

Penyusunan RPP di SMK Negeri 1 Ponorogo dilakukan secara individu, jadi setiap guru menyusun 
sendiri RPP yang akan digunakan untuk melaksanakan pembelajaran di kelas. Sedangkan di SMK Negeri 1 Jenangan Ponorogo, guru-guru dalam menyusun RPP dilakukan dengan kerja tim, dan digunakan secara bersama-sama, sehingga guru melaksanakan RPP yang sudah dibuat secara tim.

Tujuan yang dirumuskan dalam RPP masih mengarah pada tujuan pembelajaran ranah kognitif, belum mengarah ke tujuan pembelajaran pada ranah afektif maupun psikomotor. Bahkan dalam merumuskan sama dengan indikator dalam silabus.

Perencanan merupakan bagian penting yang perlu diperhatikan untuk menentukan kualitas pembelajaran. Menurut Mulyasa (2010:154) RPP merupakan pedoman pembelajaran. Guru boleh tidak membuat kurikulum, boleh tidak membuat alat peraga, bahkan dalam hal tertentu boleh tidak melakukan penilaian tetapi tidak boleh tidak membuat perencanaan.

Untuk merancang pembelajaran maka guru berpedoman pada silabus. Silabus belum memuat secara rinci apa yang harus dilakukan oleh siswa, apa yang harus dilakukan oleh guru dalam membantu siswa untuk membentuk kompetensi, apa yang harus digunakan, berapa lamanya dan berapa waktu yang diperlukan. Guru perlu menyusun perencanaan sebelum mereka melakukan kegiatan pembelajaran.

Perumusan tujuan pembelajaran dijabarkan dari indikator yang ada. Selama ini yang terjadi dalam mata pelajaran IPS hanya menyalin dari indikator di silabus. Mereka tidak melakukan analisis lain yang disesuaikan dengan materi maupun kebutuhan siswa. Tujuan yang ditentukan hanya mengarah pada ranah kognitif. Model pembelajaran yang ditentukan dalam RPP juga belum menunjukkan model pembelajaran yang mengembangkan keterampilan sosial. RPP yang dirancang oleh guru IPS belum menunjukkan pengembangan keterampilan sosial.

\section{Pelaksanaan Pembelajaran IPS}

Observasi yang dilakukan oleh peneliti dimaksudkan untuk mengetahui apakah pelaksanaan pembelajaran sesuai dengan RPP yang sudah dibuat oleh guru-guru IPS. Hasil observasi menunjukkan bahwa pelaksanaan pembelajaran mata pelajaran IPS belum melaksanakan pembelajaran yang mengembangkan keterampilan sosial, pelaksanaan pembelajaran belum sesuai dengan RPP yang disusun. Guru dalam melaksanakan pembelajaran masih banyak menjelaskan materi sehingga menghabiskan waktu, walaupun guru telah menggunakan model pembelajaran $\mathrm{co}$ - operative learning sehingga sedikit waktu untuk mengembangkan keterampilan sosial siswa. Masih ada guru IPS yang melaksanakan pembelajaran dengan konvesional yaitu dengan cara menjelaskan materi sampai waktu habis. Ada juga yang melaksanakan pembelajaran tidak sesuai dengan RPP, di RPP hanya disebutkan metode diskusi, tetapi dalam pelaksanaan pembelajaran muncul adanya kartu-kartu yang berisi pertanyaan-pertanyaan dan jawaban.

Pelaksanaan pembelajaran mata pelajaran IPS merupakan muara dari semua kegiatan pelaksanaan kurikulum mata pelajaran IPS di sekolah. Guru mata pelajaran IPS berupaya agar siswa dapat membentuk kompetensi dirinya sesuai dengan apa yang telah digariskan dalam kurikulum yaitu standar kompetensi (SK) dan komptensi dasar (KD), yang telah dijabarkan dalam RPP.

Dalam melaksanakan pembelajaran guru-guru mata pelajaran IPS di kabupaten Ponorogo ada yang menggunakan model cooperative learning, tetapi ada yang secara konvesional. Melalui model pembelajaran cooperative learning dapat dikembangkan keterampilan sosial. Karena kurangnya pemahaman guru tentang model-model pembelajaran cooperative learning, maka dalam RPP juga belum dijelaskan model pembelajaran yang dipilih, sehingga dalam pelaksanaan pembelajaran tidak sesuai dengan rencana. Apabila dilihat dari pelaksanaan pembelajaran maka proses pembelajaran yang dilaksanakan belum mengembangkan keterampilan sosial siswa, dan belum sesuai dengan RPP yang telah dibuat.

Untuk dapat mengembangkan dan melatih keterampilan sosial siswa, maka dalam pelaksanaan pembelajaran mata pelajaran IPS seorang guru dapat menggunakan model-model pembelajaran $\mathrm{Co}$ operative learning. Keterampilan sosial siswa perlu lebih banyak dikembangkan sehingga akan membekali siswa nanti untuk hidup dalam tantangan global.

\section{Penilaian Mata Pelajaran IPS}

Guru-guru IPS dalam melakukan penilaian masih banyak menggunakan penilaian pada ranah kognitif, belum menggunakan penilaian pada ranah afektif maupun psikomotorik. Penilaian dilakukan pada hasil akhir atau pada akhir kompetensi dasar dengan tes tulis. Kebanyakan guru tidak melakukan penilaian proses, ada yang melakukan penilaian afektif akan tetapi dari hasil observasi yang dilakukan peneliti hasilnya tidak maksimal. 
Penilaian yang sudah direncanakan dan diterapkan guru dengan penilaian proses dan pos tes, maka untuk penilaian selama proses pembelajaran sudah tepat dilakukan dalam menilai dan mengembangkan keterampilan sosial siswa, karena penilaian yang dilakukan guru selama proses pembelajaran adalah untuk menilai afektif dan psikomotorik anak.

Pada saat pembelajaran guru masih banyak mendominasi waktu, sehingga untuk mengadakan penilaian pada saat proses pembelajaran kurang maksimal. Dari informan yang diteliti, satu orang guru sudah merancang penilaian afektif di RPPnya dan juga sudah melaksanakan penilaian proses, tetapi hasil belum makismal. Sedangkan guru yang lain masih menggunakan tes tulis yang mengukur kemampuan kognitif saja.

\section{SIMPULANDAN SARAN}

\section{Simpulan}

Simpulan dalam penelitian adalah sebagai berikut. 1) Pemahamam guru tentang keterampilan sosial dalam mata pelajaran IPS kurang, sehingga dalam merancang pembelajaran guru banyak yang mengajarkan pemahaman konsep kurang mengembangkan pembelajaran yang mampu mengembangkan keterampilan sosial. 2) Dalam merancang RPP, tujuan yang dirumuskan dan pemilihan model pembelajaran yang ditentukan belum mengarah pada pengembangan keterampilan sosial. 3) Pelaksanaan pembelajaran mata pelajaran IPS yang dilakukan guru belum sesuai dengan rancangan pembelajaran yang telah dibuat oleh guru, terutama untuk mengembangkan keterampilan sosial siswa. Pembelajaran yang dilakukan guru cenderung teacher centered, belum mengarah ke student centered sehingga tidak banyak mengembangkan keterampilan sosial dan penggunaan model pembelajaran cooperative learn- ing belum maksimal. 4) Penilaian yang dilakukan oleh guru IPS lebih cenderung penilaian dengan tes, pada jenjang kognitif atau pemahaman, sedangkan penilaian afektif dan psikomotor diabaikan oleh guru.

\section{Saran}

Saran-saran yang diberikan kepada guru IPS adalah sebagai berikut. (1) Meningkatkan kualitas pembelajaran melalui diklat. (2) Menyusun rancangan pelaksanaan pembelajaran dengan menentukan tujuan dan model pembelajaran yang dapat mengembangkan keterampilan sosial. (3) Melaksanakan pembelajaran dengan model pembelajaran cooperative learning. (4) Mengadakan penilaian mata pelajaran IPS tidak hanya pada ranah kognitif, tetapi ranah afektif dan psikomotorik.

\section{DAFTARRUJUKAN}

Gagne, R. M. 1997. The Conditions of Learning. Third Edition. New York: Holt Rinehart and Winston.

Gardner, H. 1993. Multiple Intelligence. The Theory In Practice. New York. Basic Books.

Gunawan, R. 2011. Pendidikan IPS: Filosofi, Konsep, dan Aplikasi. Bandung: Alfabeta.

Maftuh, B. 2010. Memperkuat peran IPS dalam Membelajarkan Keterampilan Sosial dan Resolusi Konflik.. (Online), (http://file.upi. edu /Direktori/ PIDATO/3._PIDATO_PENGUKUHAN BUNYAMIN.pdf), diakses 6 Desember 2011.

Moleong, L.J. 1998. Metodologi Penelitian Kualitatif. Edisi ke-21. Bandung: PT. Remaja Rosdakarya.

Sugiyono. 2011. Metode Penelitian Kuantitatif, Kualitatif dan $R \& D$. Bandung: Alfabeta.

Mulyasa. 2010. Implementasi Kurikulum Tingkat Satuan Pendidikan Kemandirian Guru dan Kepala Sekolah. Jakarta: Bumi Aksara. 